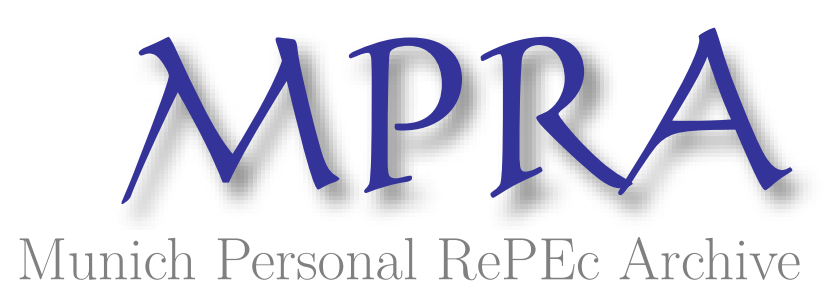

\title{
An International Perspective on Political Scandals
}

\author{
Weeber, Stan \\ McNeese State University
}

30 June 2008

Online at https://mpra.ub.uni-muenchen.de/9393/

MPRA Paper No. 9393, posted 01 Jul 2008 00:50 UTC 
Political scandals are transnational events whose ramifications transcend the consequences that any single scandal may bring upon an individual nation-state or culture. Scandals are costly to the global economy, with some of the more scandal prone countries such as the U.S. and Great Britain having spent hundreds of millions to investigate and resolve the issues raised by claims makers against one or more governmental agents. In this core of advanced capitalism that is wounded, limping along with stagnant growth and high unemployment and inflation, the costs of multiple scandals are one more item drawing capital away from "austere capitalism" and the corporate bottom line. For example, in the USA the cost of the Whitewater investigations by the Office of the Special Prosecutor was estimated at $\$ 64$ million; this being only one scandal in a country that has been scandal plagued since the mid 1980s (De Soyza, 2002; Mancuso, 2002). In semi-peripheral and peripheral nations the costs of scandal - often present as a society matures toward an industrial mode - may interfere with economic development or add to the burden of paying off foreign debt. Moreover, there is a social cost that cannot be estimated in dollars in that scandals may cause legitimacy problems for democratic or democratizing governments, making it more difficult for them to perform their functions adequately. Citizens become cynical, placing little faith in government to do anything that would be of benefit to them. This can lead to diminished interest among the best and brightest recruits to serve in government (Sabato, Stencel and Lichter, 2000; Solberg, 1990).

A global, 24 hour news cycle helps feed a self-perpetuating culture of mistrust and scandal in the media (Garment, 1991); television especially tends to convert coverage of law and politics into forms of entertainment for mass consumption. Given the limited 
time available for broadcast and the ever shortening attention span of a potentially shrinking audience, stories about political strategy, political infighting, political scandals and the private lives of politicians tend to crowd out less entertaining stories about substantive policy questions (Balkin, 1999). In this environment, oversimplification rules the day; anything that cannot be chopped down to a brief sound bite is portrayed as being hopelessly complex (Mancuso, 2002). Print and television journalists, furthermore, know that scandals can add to their employers' bottom line, as a potential breaking scandal could be a prelude to other related scandals. Then, with the tantalizing possibility that details of one or more scandals are being covered up, there are even more opportunities to report political troubles and to sell news stories (Lowi, 1988; Crouse, 1973).

Political scandals, despite their importance due to their cost and their relevance to a global, postmodern world, do not make a good subject for academic research. They are extraordinarily difficult to study. Definitional problems aside, they differ so much from one time period and one country or culture to the next that as fairly unique events they would seem to defy attempts at any form of generalization (Barker, 1994). Then, citizens of a given society may change their minds about what kinds of behavior are scandalous; for example in the United States the issue of marital infidelity by presidential candidates appeared to undergo a sea change in a relatively short period of time, going from an issue of critical importance in the Gary Hart case to an issue of little importance in Bill Clinton's case (Clark, 1992; Stoker, 1993). Further, some cultures outside the Americas place more emphasis upon the original transgression of an officeholder or candidate and less upon subsequent efforts to cover it up, as is the case in the United States (King, 1986). 
This study is designed to make two contributions to the literature on international political scandals. First, it adds to a growing pool of comparative international studies that have provided rich multicultural insight into the mechanisms by which scandals arise, are worked through, and resolved. Second, as the study draws on sociological concepts, it is a step away from "scandalology," a loosely defined area of interdisciplinary study based in political science which often suffers by presenting rich factual detail while neglecting broader analyses that look at structural issues that may be shaping the initiation and development of scandals. Scandalology studies tend to be culture and time bound, reflecting the experience of scandals within a particular nation state or region at a particular point in history.

\section{Literature Review}

Though important works in political sociology continue to neglect scandals as significant area of study (Nash and Scott, 2004; Robbins, 2005), enough work has been done on political scandals that we can no longer conclude, as Markovits and Silverstein (1988) did twenty years ago, that there is a dearth of research studies in the area. There are now some impressive encyclopedic works about scandal that provide rich documentation of specific cases or "affairs" but are lacking in their investigation of the larger social contexts that may produce scandals in the first place (Wilson and Seaman, 1986; Hyde, 1986; Callery, 1992; Palling, 1995; Parris, 1995; Grossman, 2003). These studies analyze scandals in restricted times and spaces; and for the most part are void of comparative analyses. These are less likely than other kinds of studies to shed any light upon scandals as global issues. An edited volume by Allen (1990) is a widely referenced example of this trend. Allen provides information on 175 scandals or "causes celebres" 
in 31 countries arranged alphabetically from Albania to Zimbabwe. The coverage is competent and thorough, and though favoring core nations the book also provides coverage of scandals in semi peripheral countries such as Bulgaria and Hungary, and peripheral countries including Brazil, Myanmar, and India. Allen selected cases that 1) involved political actors in some way (nonpolitical actors could be drawn in at certain points), and 2) were relatively self-contained episodes within a distinct time period. Allen's work provides one launching point from which comparative studies of scandal may begin.

Similarly time and culture bound are other works that look at historically specific aspects of certain eras and time periods; for example, examining scandals of the Watergate period or of the Reagan and Clinton administrations with special attention to the scandal laden politics of the period (Cavender, Jurik and Cohen, 1993; Morris, 2003; Shah, Watts, Domke, and Fan, 2002; Lawrence and Bennett, 2001; and Kagay, 1999). Others focus on criminological aspects of these relatively recent historical cases (e.g., Friedrichs, 2000).

Studies utilizing recent, trendy theories as an explanatory scheme are themselves products of a given place and time, for example, the use of postmodern theory to analyze and explain U.S. scandals from the 1980s onward (Lull and Hinerman, 1999; Larson and Wagner-Pacifici, 2001; and Chang, 2002). The evident purpose here is to use scandal as an instrument to deconstruct or criticize American society and its capitalistic culture. The tone of the studies tends to be deconstructive but not reconstructive, and the works are mostly cultural critiques using the scandals as inviting openings for critical cultural studies of America. 
An impressive work by Thompson (2000) attempts to discover why scandals occur, why we appear to have more scandals today than in the past, and what can be done to prevent them. He begins by offering an operational definition of political scandal: it is a moral transgression, which must be named as misconduct by an interested party, and which then faces a level of opprobrium that risks damaging the reputation of the alleged transgressor. This is the definition I embrace as I proceed with this paper.

Thompson (2000) ties the origins of scandals to contemporary sociological theory and contributes a few theories of his own. He discussed the functionalist theory of scandals, which stated that political scandals can have important consequences but they only reaffirm the norms, conventions and institutions which constitute the social order. A second theory, trivialization theory, discussed the impact that scandals have on the public's view of politics. This theory proposed that the media, by becoming preoccupied with a scandal, undermines the quality of public discourse and debate, which leads to an uniformed public. Scandals thus trivialize politics. The third theory discussed by Thompson is the subversion theory which stated that scandals enrich the public by calling into question the dominant norms of journalism and by turning the tables on the powerful and the privileged. Finally, Thompson discussed the no consequence theory, which stated that political scandals have no lasting significance on political or social life. This tying of scandals to sociological concepts advanced our thinking about scandals and also suggested lines of research that can help clarify support or non support for the ideas suggested (see also Peterson [2004]).

International studies of political scandals are beginning to attract the active interest of sociologists, political scientists, and other scholars. Scandals have been the 
object of study in Mexico, Central and South America, and several European countries (King, 1986; Wilson and Seaman, 1986; Hodder-Williams and Ceaser, 1986; Montero, Gunther and Torcal, 1998; Zirker and Redinger, 2003; Roussel, 2002; Waisbord, 1994; Levi, 1987; Jeffery and Green, 1995; Jimenez, 2004; Sherriff, O’Brien, Punch and Cannon, 1998; Herne, 1997; and Williams, 1970). These studies highlight the rich sociohistorical and socio-cultural contexts in which scandals take place, and remind us that a Eurocentric explanation for scandal may prove to be culturally limited. For example, Zirker and Redinger's (2003) study of Brazilian scandals demonstrated how intelligence agencies played a primary role in the scandal making process during the post-dictatorial phase of that country's development. Roussel (2002) studied the French "blood contamination scandal" which identified a strong disconnect between the narratives of the medical and political communities, and how difficult it is to manage crises given the complexities of democratic post-industrial societies today. Waisbord (1994) discusses how the press played a key role in the rapid rise of scandals and accusations of government corruption in Argentina in the 1990s. An implication of these studies is that democratic or democratizing nations with a free press, intense political competition, decentralized political authority and multiple access points have numerous opportunities and incentives for scandal to flourish whereas more autocratic or totalitarian states do not (Lowi, 1988; Pujas, 1998).

Comparative study helps us to understand that despite their apparent uniqueness in time and space, scandals are not necessarily unique events, and they raise broader transnational structural questions about power and legitimacy. For example, scandals can play a role in clarifying the normative bases of mass-elite interaction and political rule in 
society. They are a form of conflict, as they involve opposing social claims to the validity of norms, and the course of scandals is shaped by competing courses of actions in which instruments of power are used to try to defeat the opponent. Finally, in the light of scandal more of everyday political reality is laid bare. The societal reaction to scandal may well include much needed reforms in the political process (Neckel, 2005).

Comparative studies grounded in sociological theories would help advance systematic study of international scandals because sociology is interested in the political and sociological conditions that make scandals possible in the first place. The normative structure of society is important, particularly as it relates to the expectations and performance of politicians and state agents. Those things that become scandals are often normative definitions thought to be breached in the political process. In the USA in particular, a norm of reciprocity that is very strong develops which suggests that as the citizen has put his faith in the public servant, the latter will toil judiciously and benevolently for the public. The scandal damages the reputation of the person, the office and position, effectively disgracing each one. In these cases the usual mystification of the delegates of political power is diminished, and the scandal experience makes officials appear untrustworthy and discredited.

Additionally, the sociological study of scandals is interested in why certain behaviors are defined as scandalous while others are not. As Williams (1998) wrote, there is no obvious correspondence between the degree of controversy generated by scandals and the gravity of the alleged misdeeds. Some of those involved in scandals pay a heavy price: resignation, disgrace, and even imprisonment. Others, who seem equally culpable, somehow escape conviction and retire with dignity. 


\section{A Generalized Stage Model}

The generalized stage model proposed here is designed to assess the conditions under which scandals arise, and to explain how certain behavior comes to be defined as scandal and by what processes other seemingly equally offensive behavior escapes being labeled as scandal. A strength of the model is its multicultural emphasis, drawing insight from studies of political scandal in Italy, Spain, France, Japan, Russia, and the USA. The model also draws upon several bodies of sociological theory including functionalism, conflict theory, symbolic interactionism, and postmodernism. No claim is made that the model is all inclusive or is all capable of explaining every instance of political scandal internationally, nor are the stages themselves necessary and sufficient conditions for scandals to develop and be played out. There may be individual cases that do not conform to the stages presented, or that skip some of the stages, or that violate and nullify some of the concepts proposed.

Stage 1: Structural Conduciveness. A particular national social structure must be conducive or open to the possibility of scandal before it can occur (Smelser, 1963). Western societies are generally more open democratic structures in which the possibility of scandal or wrongdoing is real given the imperfect nature of humans and institutions. Even contentious claims are allowable under tenets of free speech and may have at least some minimal cause for thoughtful deliberation or investigation by public authorities. Such open societies are thus vulnerable to a degree of scandal susceptibility (Lull and Hinerman, 1997; Barker, 1994). Closed, totalitarian societies may allow scandals to exist, but only for specific reasons so as to make a political point. Insider accounts of closed societies paint a picture of total corruption where wrongdoing has become the 
norm, at least from the standpoint and definitions of the Western world (Caiden and Caiden, 1977; Solzhenitsyn, 1962).

Stage 2: Claims and Defenses. In this stage, the initial claims against political officials or candidates for office are made and the accused authorities are given a chance to deny or rebut the claims made against them. If the official makes a strong denial and there are no more follow-up claims or no additional claims made, then the matter dies and does not become a public issue. Vice President George H.W. Bush's strong denial that he had an affair with his appointments secretary, Jennifer Fitzgerald, essentially averted a scandal as no more claims were made and no more evidence surfaced of adultery involving the former Vice President and Fitzgerald (Kurtz, 1992; Allen and Bahrampour, 1992). This stands in contrast to the case of former presidential candidate Gary Hart, whose denials of an affair were followed up quickly with photos that clearly disproved his claims of innocence (Stoker, 1993).

Most issues that have the possibility of being framed as scandals are much more complicated that those of George Bush and Gary Hart in that evidence to support or not support the official or the official version of events may take time to work its way into the public domain, and the mass media holds much power in this regards as editorial decisions are made about which issues are deemed newsworthy and which are not. The media has power to frame the issues and their importance, and the public often follows the media's lead, at least initially. In the controversy surrounding the assassination of U.S. President Kennedy in 1963, the media strongly supported the report of the Warren Commission and public support of the Commission's report was strong for about a year before a series of books critical of the report began to surface (see Weeber, 2003). In the 
2003 Iraq War, there were similar circumstances in that the press coverage of the war which was largely supportive of the war effort appeared to follow a scripted line crafted by the Department of Defense. Some alleged that the purpose of the coverage was more to entertain than to inform. There were suspicions that the coverage was distributed to key supportive opinion makers first, and then to the public (Dadge and Schecter, 2004). Beginning in 2004, allegations surfaced of misconduct by U.S. troops which reflected the opening wave of disillusionment with the war, and these topics were initially (as the War began) considered off limits and not newsworthy (Hersh, 2004). In complex situations like these where allegations of wrongdoing may persist over time, it's possible that there could be no real resolution to the scandalous events, despite efforts by writers to "close" the matter (Posner, 1993; Bugliosi, 2007).

As these two cases demonstrate, as time passes, more circumstances that were not viewed previously as scandalous find their way into the public consciousness. Something similar happens in developing countries as they grow to approximate an industrial mode. What is considered corrupt or scandalous changes as the nation's circumstances change. Gift-giving, a culturally prescribed means of establishing good relationships among elites and lower classes in pre-industrial societies becomes something that is perceived much differently after industrialization and the establishment of an administrative state (Bourdieu, 1977; Robbins, 2005). As Smelser (1971) wrote:

Viewed from a social-psychological standpoint, institutionalizing a state apparatus simultaneously calls for a new kind of interpersonal trust in the system. A civil servant is trusted by the citizenry because of his presumed commitment to an occupational role that is implicated in the political-legal system. This depersonalization of the trust relationship is often unfamiliar to and unwelcomed by those whose trust is usually based on more immediate or particularistic relationship with others. The act of corruption can be regarded as an accommodation to the 
ambiguities that arise in the new, generalized relations between bureaucrat and clientele. Because the corrupt interchange is immediate and situational - a gift for a decision, a bribe for an act, a tip for an evasion, and so on - it brings the bureaucrat and client into a less contingent and less ambiguous relationship to one another. Corruption is a device that serves to concretize and reinfuse trust into the relationship between an impersonal authority system and its clients who may not understand or grant loyalty to that system.

Smelser would no doubt concur that the imposition or sudden adoption of liberal democracy may cause tensions in the society that encourage corruption, which in turn works to undermine the tenets of the new liberal democratic system. Solberg (1990) elaborates:

A culture where government and business relationships have been traditionally based upon personal trust will resist the distinction between the public duty and private interests of politicians. This has two results, one, corruption is likely to be widespread. Two, with this corruption resting so firmly upon a traditional cultural base, and the tenets of liberal democracy so new and so foreign, this corruption is not nearly as likely to be condemned.

What Smelser and Solberg describe here is a social process where there may be legitimate cultural reasons for engaging in behavior defined as corruption along with some lingering cultural support for "corruption" despite its obvious opprobrium in the more advanced democracies. Thus, when democratizing countries appear to be steeped in scandal, this does not mean that the countries suddenly became corrupt, but rather that historically accepted routines had finally become defined as unacceptable and illicit by law enforcement and judiciaries. The fairly recent scandals in Italy ("Bribe City"), France (blood contamination) and Spain (campaign finance) serve as examples of this process at work (Kuhn and Neveu, 2003; Pujas, 1998; Roussel, 2002).

Governmental agents, in making their defenses, may, like those in the corruption cases above, deny that anything wrong has transpired, and may actually forget the 
original incident that becomes their downfall. In doing so, they inadvertently begin a cover up of the original transgression which could take on a larger life than the original event. A strong degree of insularity and the tendency toward groupthink pervades the staffs of American presidents and make them particularly vulnerable to scandalous situations (Biggart, 1985). In memoirs of the Watergate scandal, Presidential aide H.R. Haldeman (1994) and President Nixon (1978) indicate that the original decision to deploy the CIA to obstruct the FBI's investigation into the hush money paid to the Watergate burglars was never questioned by anyone on the President's staff; it was quickly decided upon as the right course of action on a very busy day of decision making in June, 1972. And had James McCord not written his letter to the judge at his trial, there is a possibility that the Watergate affair would have ended with the jailing of the Watergate burglars (Bernstein and Woodward, 1974). Without follow up claims, it is possible that many scandalous situations die in stage 2. Scandals can abruptly end if there's no real news to report or no collective sense that a scandal has occurred, despite the best efforts of claims makers (Mancuso, 2002).

Stage 3: Conflict. Assuming that the original claims facilitate a continuing disagreement between officeholders and claims makers, or that follow-up claims ignite even more contention, then the scandalous situation enters a period of conflict. The conflict is not simply a matter of "us versus them" but also a battle for the opinion of newspaper editors, court officials, and the public, who may have the final say in the matter of what comes to be defined as scandalous and what does not (Lang and Lang, 1983; Robinson, 1974). Scandals are open processes of which the final result is uncertain and depends on the interplay of some intermediate variables (Jimenez, 1998). 
Consequently, I identify a number of such variables or factors that tend to accelerate or delimit scandal-oriented conflicts; the former obviously pushing scandals toward the next level while the delimiters function to keep the controversy under wraps, where it may simply die out, fading into history and into obscurity.

Scandal Escalators. First, conflicts escalate into major disputes when the President or top political officers of the country played or were suspected of playing a role in some corrupt or objectionable actions. The ante is upped when special prosecutors or independent counsels are appointed (Garrard and Newell, 2006; Peterson, 2004). Second, whether scandals are able to emerge in the first place and what topics they involve depend on the active participation of the public sphere in political events. Thus, conflict intensifies when there is a growing sense of injustice among the public at large. For example, concern over corruption in Spain in the spring of 1994 led to the resignations of five key officials of the Socialist Party (Jimenez, 1998). Third, conflict may become more incendiary if the public sphere is polarized, as was the case in Spain in the 1980s and 1990s where voter loyalty was split between the Socialists and the Populist Party. Fourth, if scandals resonate with diverse elements of newsworthiness, high principles, and personal drama, then the public may be drawn in to the scandal as a human interest story.

Fifth, conflict may escalate if a central forum facilitates disclosure of information, such as a Supreme Court; and, if there is a strong opponent to pursue scandal. Sixth, if the defending side is split - often a consequence of an increasing lack of public trust - then the efforts of claims makers may be more effective. Seventh, if collective framing or 
public opinion suggests that popular support for the officeholder or candidate is eroding, then the efforts of the claims makers gain momentum.

Eighth, when the norm of reciprocity is being violated, there may be an escalation in calls for resignation, even among the officeholder's respected allies. For example, when the rigors of the Watergate scandals was believed to be interfering with President Nixon's ability to lead his party and country in the summer of 1974, more and more of his Republican colleagues called for his resignation. The gravity of the situation had to be "translated" to Nixon by respected conservative Barry Goldwater.

Is there a critical tipping point at which a situation of conflict will boil over into a full scandal? It appears, certainly, that the more of the escalating factors that are present, the more likely the situation is to become a scandal. Beyond this, however, a crucial juncture may lie in the perception of the offensive behavior as being either a mistake or an error. This first is forgivable while the latter is not. The first warrants a second try or a "do over" that essentially covers the first transgression. An error does not, and being unforgivable, remains as a blemish upon the life of the officeholder. One exact tipping point could be when the norm of reciprocity has been violated, as was the case with President Nixon and his work as President of the USA when it was suspected that Watergate was taking up an extraordinary part of his administrative time. Lesser norm violations which are forgivable may not progress to full blown scandals. For example, despite the press' efforts to create a scandal when Clinton Administration official Sandy Berger stole sensitive national security documents from the U.S. Federal Archives, no scandal was forthcoming. Berger's mistake, apparently, was forgivable. 
Scandal Delimiters. There are many delimiting factors that prevent certain events that have the potential of scandal from cascading into full scandal. In Spain in the 1980s, popular support for the Socialists together with weak opposition and favorable media coverage meant that claims makers could make little headway in scandal creation, at least before the Juan Guerra case surfaced in 1990. Second, if the event or person being targeted remains an isolated event unconnected to a larger system of ill conduct or wrongdoing, there is less likelihood of a scandal developing. Such was the case with the Recruit scandal in Japan and with the Puerta and Rumasa cases in Spain which were 1980s pre-Guerra cases (Jimenez, 1998; Solberg, 1990). Third, there may be so many scandals in such a short time that the public turns away from them, turned off and fatigued by all the controversies (Mancuso, 2002). It may be that moral expectations toward political power no longer exist after repeated scandals, and the public is cynical. It could also be true, additionally, that competing news events for a while drown out stories of scandal, as was the case after the September $11^{\text {th }}$ terrorist attacks (Weeber and Turner, 2007).

Fourth, if national consensus is unquestioned, as was the case in the USA following September $11^{\text {th }}$, then normally newsworthy events often go unnoticed in the wake of collective goodwill and patriotism. U.S. Vice President Dick Cheney's unusual accounting methods as CEO of Halliburton were a potential scandal in the making, but were basically drowned out in the fall of 2001 by War on Terrorism news. Such an exception from scandal making does not have a long shelf life, however, as Trent Lott found out: his favorable comments about the racist Strom Thurmond cost him his job as Senate Majority Leader in 2002 (Weeber and Turner, 2007). 
Fifth, if the claims makers by accusations "punish" the errant public servant to excess, a public backlash in support of that servant may stymie the efforts of claims makers to have their officially validated by the judicial process. This may have occurred in the Clinton-Lewinsky scandal as the public believed the Special Prosecutor had lost his sense of reasonable proportion in his effort to convict Bill Clinton at all costs. As Mancuso (2002) wrote, Special Prosecutor Kenneth Starr abandoned all considerations of measured and moderated judgment. He was stigmatized as someone obsessed with his subject and willing to conduct any manner of experiment that might lead him to more evidence. Hence, though the press and prosecutors may stridently pursue a scandal, the public may purposely not buy into it (Neckel, 2005; Toobin, 1999; Sabato, Stencel and Lichter, 2000; Morris, 2003; Shaw, Watts, Domke, and Fan, 2002).

Sixth, the powerful may on occasion successfully delimit the issues that can be defined as scandal. This occurred in the Cheney-Halliburton case, as George W. Bushappointed SEC commissioners neglected to pursue the strongest penalties against both the company and Cheney. Seventh, any potential scandal runs into the problem of not having enough time to sufficiently draw up charges against the accused officeholder or candidate. Much like a bill that can "stall" in a legislature and not be brought to vote, charges against an official may run into time deadlines that cannot be met (Mancuso, 2002).

Eighth and finally, scandals involving officials below that of top ranking officials are less likely to result in charges being brought and special investigations or special prosecutors being mobilized for action. It is difficult to stimulate public interest in such cases. 
Again, the question of a critical tipping point emerges with respect to the factors delimiting a scandal. An absence of accelerants together with the existence of a larger number of delimiting factors would be predictive of no scandal developing. Once again, the norm of reciprocity may be of special importance. If this norm is unbroken and the problem of the officeholder or candidate can be effectively framed in that person's private sphere as unrelated to his public work, then a catastrophic scandal has been avoided. Probably the classic case of damage control that deflected a scandal was the $\underline{60}$ Minutes interview where then candidate Bill Clinton along with his wife Hillary were able to skillfully frame governing as public sphere behavior and Bill Clinton's womanizing as personal, private sphere behavior with an emphasis on how the two are completely separate (Toobin, 1999). Rozell and Wilcox (2000) argued that as long as the President (or by extension any leader) operates successfully in his or her job, it is easier for the public to separate the public and private spheres, and to forgive the official's private transgressions.

The information regarding the acceleration and delimiting of conflict can be summarized as follows. The pushes toward scandal are equivalent in number to the pulls away from it; yet, the former would appear to carry more weight than the latter in determining whether or not a scandal will emerge from a situation of prolonged conflict between claims makers and public officials. The worldwide proliferation of scandals in itself would appear to validate this statement.

Stage 4: Acknowledgment. To claims makers, an important validation of their efforts occurs when political officials do not survive their scandals, having to leave office or face sanctions up to imprisonment for their scandalous behavior. Claims makers have 
much success, judging from world newspaper headlines and U.S. congressional publications that keep track of errant American Congressmen. The exact moment of acknowledgment is unknown, although journalists speak of scandals as "having legs," or staying power. Here, the story is one that will endure for a while, and consequences for the official may be forthcoming. Ironically though, there are also many cases that, while clearly scandalous in the public's collective mind, never get an official stamp of wrongdoing or guilt. The Clinton-Lewinsky scandal that left Clinton in office is one example; President Ford's full pardon issued to Richard Nixon is another. In these cases there is a diffused public acknowledgement of scandal but not an official one.

Stage 5: Resolution. This stage concerns what happens in the aftermath of the scandal, regardless of whether it has or has not been officially acknowledged. The consequences can be quite severe, as in the case of the Bribe City scandal in Italy which resulted in the break-up of Italy's main government parties, the transformation of the entire party system and the onset of a process of regime transition (Garrard and Newell, 2006).

A functionalist approach to scandal emphasizes positive effects of the phenomenon including how it reinforces the community's collective consciousness. Scandals, at least temporarily, may lead to a higher standard of ethics along with new rules or laws designed to prevent future scandals (Jimenez, 1998; Mackenzie and Hafkin, 2002). Resolution of the conflict may restore faith in governmental processes, and the scandal may provide a new direction, a point of departure from the scandalous course that the government had been following in the past (Barker, 1994) 
In contrast Solberg (1990), reflecting upon his study of Japan's Recruit scandal, fears the cascading effects that scandals can have. He sees an unending cycle of Japanese scandal followed by reform (which defines more behavior as scandal) followed by scandal, followed by reform. With each cycle scandalous behavior is easier to find because there is more of it being officially recognized. He fears that Japan could become paralyzed by scandal. Mancuso (2002) voices similar concerns for America, especially the media's hunger for scandal and its efforts to manufacture scandal where none exists.

Potentially most frustrating of all is the situation where scandals exist in perpetuity with no sign of resolution or closure at all. The controversies over the assassination of President Kennedy and over the necessity of the 2003 Iraq War are two examples previously mentioned. It is possible that questions about who did what to whom and for what purpose could be debated by historians and publics for millennia to come.

\section{Conclusion}

This comparative study of political scandals in Italy, France, Spain, Japan, Russia and the United States led to the development of a sociology-based generalized stage model that is an initial step in explaining why scandals arise and how they are worked through and resolved. A crucial phase is the conflict phase between elites and masses, where potential scandals may die while others accelerate. The question of which events evolve to scandal and which do not is also likely to be worked through in this phase. The norm of reciprocity between officials and the public played a significant role in both scandal acceleration and scandal delimitation. As accelerant, a broken norm of reciprocity leaves the official paralyzed by the scandal and incapable for performing his 
or her duties effectively. As delimiter, an unbroken norm of reciprocity can salvage the official's job when that person's scandalous behavior can be framed within and successfully limited to his or her private sphere, leaving the public sphere unaffected.

\section{References}

Allen, Louis. 1990. Political Scandals and Causes Celebres Since 1945. Chicago: St. James Press.

Allen, Stewart and Tara Bahrampour. 2002. "The Other Jennifer." Mother Jones, 17, 4, July/August, 11.

Balkin, J.M. 1999. "How Mass Media Simulate Political Transparency.” Cultural Values, 3, 4, Oct, 393-413.

Barker, Anthony. 1994. "The Upturned Stone; Political Scandals and Their Investigative Processes in Twenty Democracies." Crime, Law and Social Change, 21, 337-373.

Berstein, Carl and Bob Woodward. 1974. All the President's Men. New York: Simon and Schuster.

Biggart, Nicole W. 1985. "Scandals in the White House: An Organizational Explanation." Sociological Inquiry, 55, 2, Spring, 109-130.

Bourdieu, Pierre. 1977. Outline of a Theory of Practice. New York: Cambridge University Press.

Bugliosi, Vincent. 2007. Reclaiming History. New York: W.W. Norton.

Caiden, Gerald and Naomi Caiden. 1977. "Administrative Corruption.” Public Administration Review, 37, 3, May/June, 301-309.

Callery, Sean. 1992. Scandals: Gripping Accounts of the Exposed and Deposed. New York: Smithmark Publishers.

Cavender, Gray, Nancy Jurik and Albert Cohen. 1993. "The Baffling Case of the Smoking Gun: The Social Ecology of Political Accounts in the Iran-Contra Affair." Social Problems, 40, 2, May, 152-166.

Chang, Michael. 2002. "Racial Politics in an Era of Transnational Citizenship." Dissertation Abstracts International, A: The Humanities and Social Sciences, 63, 2 , Aug, 766A-767A.

Clark, Charles. 1992. Politicians and Privacy. Washington, D.C.: CQ Press. 
Crouse, Timothy. 1975. The Boys on the Bus. New York: Ballantine Books.

Dadge, David and Danny Schecter. 2004. The War in Iraq and Why the Media Failed Us. Westport, CT: Praeger.

De Zoysa, Richard. 2002. "American Government, Public Policy and the Prospects for Reform." Contemporary Politics, 8, 1, 69-78.

Friedrichs, David. 2000. "Crime in High Places: A Criminological Perspective on the Clinton Case." Sociology of Crime, Law, and Deviance, 2, 281-300.

Garment, Suzanne. 1991. Scandal: The Crisis of Mistrust in American Politics. New York: Times Books.

Garrard, John and James Newell. 2006. Scandals in Past and Contemporary Politics. New York: Palgrave.

Grossman, Mark. 2003. Political Corruption in America : An Encyclopedia of Scandals, Power and Greed. Santa Barbara, CA: ABC-CLIO.

Haldeman, Robert. 1994. The Haldeman Diaries. New York: G.P. Putnam's.

Herne, Claude. 1997. "Business and Corruption in Belgium: Scandals and Transgressions of Capital or Democracy in Danger from Silver." Contradictions, 81-82, Jan, 32-90.

Hersh, Seymour. 2004. Chain of Command. New York: HarperCollins.

Hodder-Williams, Richard and James Ceaser. 1986. Politics in Britain and the United States. Durham, NC: Duke University Press.

Hyde, Montgomery. 1986. A Tangled Web. London: Constable.

Jeffrey, Charlie and Simon Green. 1995. "Sleaze and the Sense of Malaise in Germany." Parliamentary Affairs, 48, 4, Oct, 677-687.

Jimenez, Fernando. 2004. "The Politics of Scandal in Spain: Morality Plays, Social Trust, and the Battle for Public Opinion." American Behavioral Scientist, 47, 8, Apr, 10991121.

1998. "Political Scandals and Political Responsibility in Democratic Spain.” West European Politics, 21, 4, 80-103.

Kagay, Michael. 1999. "Presidential Address: Public Opinion and Polling During Presidential Scandal and Impeachment." The Public Opinion Quarterly, 63, 3, Fall, 449-463. 
King, Anthony. 1986. “Sex, Money and Power.” Pp. 173-204 in Richard HodderWilliams and James Ceaser (Eds.) Politics in Britain and the United States. Durham, NC: Duke University Press.

Kuhn, Raymond and Erik Neveu. 2003. Political Journalism: New Challenges, New Practices. New York: Routledge.

Kurtz, Howard. 1992. "Bush Angrily Denounces Report of Extramarital Affair As A 'Lie."” Washington Post, August 12.

Lang, Gladys and Kurt Lang. 1983. The Battle for Public Opinion. New York: Columbia University Press.

Larson, Magali and Robin Wagner-Pacifici. 2001. "The Dubious Place of Virtue: Reflections on the Impeachment of William Jefferson Clinton and the Death of the Political Event in America." Theory and Society, 30, 6, Dec, 735-774.

Lawrence, Regina and Lance Bennett. 2001. "Rethinking Media Politics and Public Opinion: Reactions to the Clinton-Lewinsky Scandal.” Political Science Quarterly, 116, 3, Fall, 425-446.

Levi, Michael. 1987. "Crisis: What Crisis? Reactions to Commercial Fraud in the United Kingdom." Contemporary Crises, 11, 3, 207-221.

Lowi, Theodore. 1988. "Foreword." Pp. vii.-xii in A. Markovits and M. Silverstein (Eds.) The Politics of Scandal: Power and Process in Liberal Democracies. New York: Holmes and Meier.

Lull, James and Stephen Hinerman. 1999. Media Scandals: Morality and Desire in the Popular Culture Marketplace. New York: Columbia University Press.

Mackenzie, Calvin and Michael Hafkin. 2002. Scandal Proof. Washington, DC: Brookings Institution Press.

Mancuso, Maureen. 2002. "A Thousand Brooms, A Thousand Buckets: Accountability and the Institutional Investigation of Scandal." Canadian Review of American Studies, $32,3,285-300$.

Markovits, Andrei and Mark Silverstein. 1988. The Politics of Scandal: Power and Process in Liberal Democracies. New York: Holmes and Meier.

Montero, Jose, Richard Gunther and Mariano Torcal. 1998. "Attitudes Toward Democracy in Spain: Legitimacy, Discontent and Disaffection.” Revista Espanola de Investigaciones Sociologicas, 83, July-Sept, 9-49. 
Morris, Lorenzo. 2003. "Presidential Impeachment, Ideology, and Party Politics: Comparing 1868 to 1999." National Political Science Review, 9, 206-229.

Nash, Kate and Alan Scott. 2004. The Blackwell Companion to Political Sociology. Malden, MA: Blackwell.

Neckel, Siphard. 2005. "Political Scandals: An Analytical Framework." Comparative Sociology, 4, 1-2, 101-111.

Nixon, Richard. 1978. RN: The Memoirs of Richard Nixon. New York: Grosset and Dunlap.

Palling, Bruce. 1995. The Book of Modern Scandal. London: Weidenfeld and Nicolson.

Parris, Matthew, David Prosser and Andrew Pierce. 1995. Great Parliamentary Scandals: Four Centuries of Calumny, Smear, and Innuendo. London: Robson Books.

Peterson, Keely, 2004. Political Scandal and Policy Creation. M.A. Thesis, Duquesne University.

Posner, Gerald. 1993. Case Closed: New York: Random House.

Pujas, Veronique and Martin Rhodes. 1998. Party Finance and Political Scandal in Latin Europe. Florence: European University Institute.

Robbins, Richard. 2005. Global Problems and the Culture of Capitalism. Boston: Allyn and Bacon.

Robinson, Michael. 1974. "The Impact of the Televised Watergate Hearings." Journal of Communication, 24, 2, Spring, 17-30.

Roussel, Violaine. 2002. "Changing Definitions of Risk and Responsibility in French Political Scandals." Journal of Law and Society, 29, 3, September, 461-486.

Rozell, Mark and Clyde Wilcox. 2000. The Clinton Scandal and the Future of American Government. Washington, D.C.: Georgetown University Press.

Sabato, Larry, Mark Stencel and Robert Lichter. 2000. Peepshow: Media and Politics in an Age of Scandal. Lanham, MD: Rowman and Littlefield.

Shah, Dhavan, Mark Watts, David Domke, and David Fan. 2002. "News Framing and Cueing of Issue Regimes: Explaining Clinton's Public Approval in Spite of Scandal." The Public Opinion Quarterly, 66, 3, Fall, 339-370. 
Sherriff, Andrew, Gary O'Brien, Eddie Punch and Matthew Cannon. 1998. "The Dunnes Payments Scandal, Charles Haughey and Contemporary Irish Political Culture."

Crime, Law and Social Change, 30, 1, 43-65.

Smelser, Neil. 1971. "Stability, Instability and the Analysis of Political Corruption.” Pp. 9-12 in Bernard Barber and Alex Inkeles (Eds.) Stability and Social Change. Boston: Little, Brown and Co. 1963. Theory of Collective Behavior. New York: Free Press of Glencoe.

Solberg, Eric. 1990. The Anatomy of Japanese Political Scandal. A.B. Thesis, Harvard University.

Solzhenitsyn, Aleksandr. 1962. One Day in the Life of Ivan Denisovich. New York: Dutton.

Stoker, Laura. 1993. "Judging Presidential Character: The Demise of Gary Hart." Political Behavior, 15, 2, June, 193-223.

Thompson, John. 2000. Political Scandal: Power and Visibility in the Media Age. Malden, MA: Blackwell.

Toobin, Jeffrey. 1999. A Vast Conspiracy. New York: Random House.

Waisbord, Silvio. 1994. "Knocking on Newsroom Doors: The Press and Political Scandals in Argentina." Political Communication, 11, 1, January-March, 19-33.

Weeber, Stan. 2003. Lee Harvey Oswald. Lewiston, NY: Edwin Mellen Press.

Weeber, Stan and Billy Turner. 2007. "Politics, Collective Framing, and Scandal: U.S. Scandal Management from 'Checkers' to Halliburton” Contemporary Law and Justice Journal, 7, Fall, 71-93.

Williams, Philip. 1970. Wars, Plots and Scandals in Post War France. Cambridge: Cambridge University Press.

Williams, Robert. 1998. Political Scandals in the USA. Edinburgh: Keele University Press.

Wilson, Colin and Donald Seaman. 1986. Scandal! New York: Stein and Day.

Zirker, Daniel and Matthew Redinger. 2003. "The Military, Intelligence Agencies, Political Scandals, and Democracy in Brazil." Journal of Political and Military Sociology, 31, 1, Summer, 39-55. 